\title{
Corporate Taxes and Foreign Direct Investments: An Impact Analysis
}

\author{
Onome Christopher Edo ${ }^{1 *} \quad$ Anthony Okafor ${ }^{2} \quad$ Akhigbodemhe Emmanuel Justice $^{3}$ \\ 1.Department of Accounting, University of Benin, Nigeria \\ 2.School of Accountancy, University of Louisville, U.S \\ 3.Department of Economics, University of Benin, Nigeria
}

\begin{abstract}
We investigate the effects of corporate taxes on the flow of foreign direct investments (FDI) in Nigeria between 1983 and 2017. The study adopts the ex-post facto research design; secondary data were sourced from the World Bank Development indicator, Central Bank of Nigeria database, and Federal Inland Revenue database. Research data was analyzed using the Error Correction Model (ECM). The coefficient of determination $\left(\mathrm{R}^{2}\right)$ showed that about 77 percent of the systematic changes in FDI are attributed to the combined effect of all the explanatory variables captured in the study. We find that Company Income Tax, Value Added Tax, and Custom and Excise Duties have a significant but negative relationship with FDI. In contrast, Tertiary Education Tax has a positive association with FDI. Also, Exchange Rate had a negative but significant relationship with FDI; Inflation had an insignificant but positive association with FDI, while GDP growth rate and Trade Openness showed a positive and significant association with FDI. Our findings deviate from previous results, as we find new evidence that a higher Education tax rate influences FDI, and the emerging evidence on the effect of non-tax variables on FDI inflow.
\end{abstract}

Keywords: Corporate Taxes, Foreign Direct Investments, Error Correction Model, Nigeria, Non-tax Variables.

JEL Classification: E22, F21, H2, P33.

DOI: $10.7176 / \mathrm{PPAR} / 10-9-07$

Publication date:September $30^{\text {th }} 2020$

\section{Introduction}

Multinational firms seeking opportunities to create global footprints desire economies with low tax burdens. Governments across the globe compete to have foreign investments to bridge revenue shortfalls, unemployment, and knowledge gap. The emergence of the corona-virus pandemic has further crippled global economic activities, especially with the shutdown of several businesses. Nigeria with a population of over 200 million people and adjudged the giant of Africa has had limited foreign direct investments since its independence in 1960 compared to South Africa which is Africa's second largest economy (Aderibigbe, 2017). Despite its size, and massive endowment of mineral resources, the country is still grappling with developmental challenges. Notwithstanding its oil wealth and other mineral resources, a large chunk of its population still lives in poverty, with high levels of unemployment, infrastructural deficit, and corruption. Nigeria's economic woes have been exacerbated by its weak foreign reserves and the continued decline crude oil prices in the international market, which is Nigeria's economic mainstay.

Economic diversification, therefore, appears to be an antidote to the present-day challenges facing the country. Investment decisions are crucial to economic performance, if Nigeria must meet the United Nations Sustainable Developmental goals, then it must take steps to reassess the factors possible of enhancing its sustainability and development. FDI remains a dominant source of financing for developing countries and has continued to dominate the discourse on economic development and sustainability (Olaleye, 2016).

FDI was defined by the United Nations Conference on Trade and Development (UNCTAD, 2017: P3) "as an investment in a long term relationship and reflecting a lasting interest and control by a resident entity in one country (foreign direct investor or parent enterprise) in an enterprise resident in another country other than that of the foreign direct investor". Bajrami and Nazmi (2019) further buttressed that it involves the injection of foreign capital into enterprises operating in a different country other than the investor's country.

Foreign Direct Investment (FDI) can be categorized as a Greenfield investment - which is a method of establishing a whole operation in a foreign country including the purchase of property, plant, and machinery. Foreign Direct Investments (FDI) can also be categorized as Brownfield investments which is the acquisition of an existing business or a merger (Okafor, 2019).

Over the years, Nigeria has ranked high among foreign capital recipients (Oguh, 2016). However, there has been a consistent decline in the flow of foreign investments and much more the incessant reversals of capital. The National Bureau of Statistics (2017) revealed that FDI flow to Nigeria in 2017 totaled \$981 million, a far cry from previous performances, and a decline of $41 \%$ in the last ten years. This decline is attributed to infrastructural decay, unfavorable tax policies, and incentives (Taiwo et al., 2017; World Bank, 2018).

Globally, governments initiate policies to reduce the burden on foreign investors, it is hoped that such policies will become an enabler for FDI inflows and a reduction in capital flight. For instance, the United Kingdom reduced 
its corporate tax rate from $30 \%$ to $19 \%$, Netherland from $30 \%$ to $25 \%$, Finland from $26 \%$ to $20 \%$. Denmark decreased its tax to $22 \%$ from $28 \%$, Switzerland tax rate stands at $21.2 \%$, Ireland $12.5 \%$, Poland from $28 \%$ to $19 \%$, Bulgaria's company income tax rate stands at 10\%. Presently, the United States under the leadership of Donald Trump reduced its tax rate from 35\% to $21 \%$, amongst other incentives (Deloitte, 2018; Djankov, 2017; UNCTAD, 2018). These policy changes are in consonance with prior studies (Babatunde \& Adepeju, 2012; Okolo et al., 2016; Olaniyi et al., 2018; Tayo -Tiwo, 2020; Ugwu, 2018). However, other researchers have drawn conclusions that taxes do not affect the flow of FDI in a country (Julio et al., 2013; Haberly \& Wojick, 2014; Kinda, 2014; Saidu, 2015; Sheedy et al., 2017).

Taxation is defined as a pecuniary burden upon individuals and businesses or property to support government expenditure. It is an enforced and compulsory contribution, exacted pursuant to legislative authority and is any contribution imposed whether under the name of duty, custom excise, levy or other name (National Tax policy, 2012: 1). The multiplicity of taxes in Nigeria is believed to disrupt the flow of foreign investments and sustenance of business in the country. Akinwunmi et al., (2017) describe this as a yoke that frustrates investors and scares prospective investors. Corporate taxes prevalent in Nigeria include but are not limited to company income tax charged at $30 \%$ of profit, value-added tax charged at $5 \%$, tertiary education tax charged at $2 \%$ of assessable profit, capital gains tax charged at $10 \%$ of the gains on a chargeable asset, customs and excise duty, the Nigerian information technology levy, as well as a hotel consumption tax.

Review of literature suggests that a number of studies have been conducted to determine the effect of taxes on FDI. Most of these studies are limited in scope with most focusing on the effect of tax variables on a particular sector of the economy. Others have considered the relationship between these variables but with limited number of years. Our study attempts to bridge this gap by carrying out an extensive review of the effect of corporate taxes and non-tax variables on FDI for an expanded period of 37. Examining this relationship for an extended period has become necessary given the limited sample period in most studies, and to avoid errors associated with testing small samples.

This study contributes to extant literature by unveiling new evidence on the effects of tax and non-tax variables on FDI as against previous studies that have focused mainly on the effect of tax variables on FDI. Consequently, this study seeks to examine empirically the effect of corporate income taxes and non-tax variables on FDI in Nigeria. The overarching intention of this study is to investigate the impact of corporate taxes and nontax variables on FDI in Nigeria between 1983 and 2017.

\section{Literature Review}

The tax competition theory by Oates (1972) suggests that economies use tax reductions as stimulant to FDI flow. Thus, implying that higher taxes deter FDI flow, therefore, there is a trade-off between competing for new FDI and the level of revenue generated from corporate taxes. Babatunde and Adepeju (2012) studied the impact of tax incentives in the oil and gas sector, their results show a significant relationship between tax incentives and FDI. The study's findings cannot be generalized because of its limited focus. Saidu (2015) studied corporate taxation and FDI in Nigeria, and found that corporate taxes influence the volume and location of FDI. However, the study only incorporated company income tax rate as the only variable, ignoring other corporate tax variables and the aggregate effect of other taxes on FDI. Seeking to address the gaps George and Bariyima (2015) studied tax incentives and FDI. They found that the response of FDI to tax is negatively significant which aligns with the findings of (Saidu, 2015). Amuka and Ezeudeka (2017) studied the effect of taxes and the flow of FDI to non-oil sector. The study used company income tax as the only tax variable and produced similar results to those of (Babatunde \& Adepeju, 2012: Saidu, 2015).

Akinwunmi et al. (2017) studied the effect of the multiplicity of taxes on FDI. The study differs from other studies as they capture the other tax variables such as, value-added tax, custom and excise duties, education tax and a non-tax variable, inflation rate. Other studies such as Obida and Nurudeen (2010); Hunady and Orviska (2014); Kersn-Skabic (2015) after examining the relationship between FDI and its determinants, found that the principal determinants of FDI are the market size of the host country, deregulation, exchange rate, depreciation, and political stability. The effect of taxes was not included in the model. Tessema (2008) argues that multinational corporations (MNCs) operating in Africa are denying African States a huge amount of revenue, mainly using the gaps created by the tax incentives. As a result, African States are losing revenues that could have been used for improving the socio-economic situation of their population.

Shafik et al., (2011) studied the effect of taxation on the location of multinational firms in Germany from 2005 - 2007 using a sample of 2332 foreign firms. A logit model was used to estimate the research data. Shafik et al., (2011) reported that taxation is crucial in determining investment location decision. In detail, the result reveals that an increase in corporate tax by $10 \%$ reduces the probability of choosing a country to host Greenfield investment by about $6.4 \%$. Nikula and Kotilainen (2012) studied the determinants of FDI flow in nine countries of the Baltic Sea region. The study's findings identified low tax rates as the singular reason why the Baltic Sea region is the preferred investment destination. 
Similarly, Cung and Hua (2013), using research data between 1999 and 2011, examined the effect of tax burden on FDI flows in Vietnam. The result of the study indicates that tax burden and unit labor costs significantly impacted FDI inflows. Kubicova (2013) examined the role of corporate tax in attracting FDI flows in the European Union using panel data covering a period of 2003 to 2011. Variables used in the study include the flow of foreign direct investment in the EU as the dependent variable while the explanatory variables are gross domestic product per capita, inflation, labor costs, infrastructure, corporate tax, the degree of the economy's openness and the effective tax rate on profit and capital assets. The result shows that effective tax rate and statutory company income tax were insignificant and weak, but had an adverse effect on FDI flow to E.U. countries.

Camara (2014) investigated the effect of corporate tax on foreign investments in Ghana; FDI flow was the dependent variable, while the independent variables were exchange rate variations, company income tax, export, interest rate and life expectancy of human capital. Secondary data was obtained from the Ghana's Investments Promotion Centre from 1986 to 2012. The regression result compared with those of Cung and Hua (2013). The coefficient of corporate tax was statistically significant at $1 \%$ showing that corporate taxes affect FDI flows negatively, and that an increase in $1 \%$ of tax will lead to a decrease in FDI flow.

Hunady and Orviska's (2014) study negates the results of Cung and Hua (2013) and Kubicova (2013). The study investigated the determinants of FDI flows into the European Union using panel data and the regression model. The study covered the period from 2004 to 2011 and focused on statutory effective tax rates and FDI from twenty-seven E.U countries. The result demonstrates that corporate taxes had no significant effect on FDI flow, thereby, contradicting previous results.

This result agrees with previous work carried out by Hansson and Olofsdotter (2010) where they examined the factors responsible for the differences in tax policies between the old E.U. member countries and the new E.U. member countries. The study adopted an implicit model to determine the flow of FDI flow. Panel data was obtained from twenty-seven E.U. countries from 1995-2006. The study found no link between tax and the decision to invest, and the differentials in tax rate were not a determinant to FDI decisions.

Similarly, Odhiambo (2013) examined the relationship between investment rate and corporate taxes in Kenya. The regression result shows that the variation in investment rate was poorly explained by the variation in corporate tax. The result corroborates Musyoka (2012) who examined the relationship between tax incentives and FDI in Kenya. Musyoka (2012) observed no significant improvement in FDI flow after implementing tax incentives. These findings are in consonance with that of Hungerford (2012), the study examined FDI inflow in the USA using a time series data between 1945 and 2009. Hungerford (2012) concludes that the reduction in tax rates had little association with investment, productivity, growth and savings.

Following the metrics adopted in previous studies, Golpira et al, (2016) investigated data from the European Union region between 2000 and 2012 to determine the effect of corporate income tax on foreign direct investments in Central and Eastern Europe. Golpira et al, (2016) analyzed tax and non-tax variables such as market size, market distance, labor cost, level of privatization, openness, inflation including corporate income effective tax rate. The regression results show that corporate tax has a significant impact on FDI into the Central and Eastern European countries.

Andre (2015) examined the effects of corporate taxes on FDI in Portugal. The study assesses the impact of taxes on FDI in Portugal by analyzing FDI data from 1996 - 2013. Key variables examined in the study include FDI flows as the dependent variable, while corporate tax, exchange rate, corruption index, labor cost, public investment per GDP were the explanatory variables. Ordinary least squares (OLS) and multiple regressions were the estimation method applied in the study. The result shows that corporate taxes are negatively correlated with FDI while exchange rate and corruption had a negative relationship with FDI flows.

\section{Hypotheses Development}

Hypothesis $H_{1}$ : Company income tax has no significant impact on FDI in Nigeria

Using this hypothesis, we examine the impact of company income tax on FDI in Nigeria. Cassou (2006), while investigating the impact of tax policy on foreign direct investment flows between the U.S. and other countries, found the home country's corporate tax rates to have a significant effect on investment flows. Research data obtained from the World Development Indicators and the Central Bank of Nigeria database will be analyzed to validate this hypothesis.

Hypothesis $\mathrm{H}_{2}$ : Value added tax has no significant impact on FDI

The effect of the value-added tax of the host country on the FDI will be analyzed through hypothesis 2 . Valueadded tax and its effect on growth and investment flows has been a subject of many studies. In their analysis of 69 countries ranked among high-income, middle-income and low-income countries between 1970 and 2009, Santiago and Yoo (2012) established that value-added taxes on sales were associated with faster growth. The study utilizes data from the Federal Inland Revenue Service in analyzing hypothesis 2

Hypothesis $H_{3}$ : tertiary education tax has no significant impact on FDI in Nigeria

Hypothesis 3 examines the impact of tertiary education tax on FDI in Nigeria. The effect of tertiary education tax 
on the flows of investments has scarcely been studied. Therefore, data from the CBN Statistical bulletin and Federal Inland Revenue Service will be examined empirically to determine any association between tertiary education tax on FDI flows in Nigeria between 1983 and 2017.

Hypothesis $\mathrm{H}_{4}$ : custom and excise duty has no significant impact on FDI inflow in Nigeria

In hypothesis 4 , we examine the impact of custom and excise duty charges on FDI flows in Nigeria. Olaniyi et al, (2018) had previously studied the effect of tax policy incentives on the flow of FDI in Nigeria and found that custom and excise duties had a significant impact on foreign direct investment. Publicly available data from CBN Statistical Bulletin and the Federal Inland Revenue Service will be analyzed to determine whether a statistical relationship exists.

\section{Data and Methodology}

Panel data for this study was obtained from secondary sources. The secondary sources include the World Development Indicators of World Bank (Foreign direct investment, net flows (\% of GDP) and the Central Bank of Nigeria annual statistical bulletins and various accounts, Federal Inland Revenue Service (Companies Income Tax, Value added tax, Tertiary Education tax and Custom and excise duties), other control variables were also introduced and includes (Inflation, Trade Openness, Exchange rate, and GDP growth rate.)

The estimation model is predicated upon the tax competition theory which was developed by Oates (1972). Tax competition theory opines that governments lower fiscal burdens to encourage the flow of productive resources, and a means of attracting FDI. Wakaguyu, et al., (2017) notes that advancing this theory will lead to an increase in skilled human capital and financial investments. This theory further asserts that tax competition is an important determinant of investment distribution across countries. This theory motivates the investigation into the impact of reduced corporate taxes (CIT, TET, VAT, and CED) on FDI, and has given rise to the formulation of the hypotheses for the study as follows.

$F D I_{t}=\mathrm{f}(\mathrm{CIT}, \mathrm{VAT}, \mathrm{TET}, \mathrm{CEDUT}, \mathrm{EXRT}, \mathrm{INFL}, \mathrm{RGDPGR}, \mathrm{TOPN})$,

The structural models are presented below;

$F D I_{t}=\beta_{0}+\psi \cdot C I T_{t}+u_{t}$

$F D I_{t}=\beta_{0}+{ }^{\prime} V A T_{t}+u_{t}$

$F D I_{t}=\beta_{0}+\omega T E T_{t}+u_{t}$

$F D I_{t}=\beta_{0}+\phi$.CTEDUT $T_{t}+u_{t}$

$F D I_{t}=\beta_{0}+\tau_{1} E X R T_{t}+u_{t}$

$F D I_{t}=\beta_{0}+\tau_{2 .} I N F L_{t}+u_{t}$

$F D I_{t}=\beta_{0}+\tau_{3} R G D P G R_{t}+u_{t}$

$F D I_{t}=\beta_{0}+\tau_{4 .} T O P N_{t}+u_{t}$

Consequently, the augmented structural model is below;

$F D I_{t}=\beta_{0}+\eta F D I_{t}+\psi C I T_{t}+{ }^{\prime} \Upsilon V A T_{t}+\omega T E D U T_{t}+\phi_{.} C E D U T_{t}+\tau_{1 .} E X R T_{t}+\tau_{2 .} I N F L_{t}+\tau_{3 .} R G D P G R_{t}+$ $\tau_{4}$ TOPN $N_{t}+u_{t}$

Where:

FDI denotes foreign direct investments in Nigeria, which is the dependent variable; CIT signifies Companies Income Tax in Nigeria; VAT denotes Value added tax in Nigeria; TET indicates Tertiary Education tax in Nigeria; CEDUT represents Custom and excise duties in Nigeria; EXRT represents Exchange Rate, INFL represents Inflation Rate, RGDPGR represents Real GDP Growth Rate, TOPN represents Trade Openness. Where, Exchange Rate, Inflation Rate, real GDP Growth Rate, and Trade Openness are the control variables in the estimation model.

The estimation technique adopted in examining the impact of corporate taxes on the flow of FDI in Nigeria is the Co-integration and Error Correction Mechanism (ECM). The variables will be tested for unit root, following the procedure advanced by Dickey and Fuller (1981) and complemented by Phillip and Perron (1988). E-Views version software was used in performing the analyses. Table 1 shows the summary and operationalization of the study variables. 
Table 1: Operationalisation of Variables

\begin{tabular}{|c|c|c|c|c|c|}
\hline S/No. & Variables & Proxy & Measurement & Sources & $\begin{array}{l}\text { Apriori } \\
\text { sign }\end{array}$ \\
\hline 1. & $\begin{array}{l}\text { Foreign Direct } \\
\text { Investment } \\
\text { (Dependent } \\
\text { Variable) } \\
\end{array}$ & FDI & Annual FDI inflow & $\begin{array}{l}\text { World Bank } \\
\text { development indicator, } \\
\text { Nigerian stock } \\
\text { exchange manual, }\end{array}$ & Nil \\
\hline 2. & $\begin{array}{l}\text { Company Income } \\
\text { Tax } \\
\text { (Independent } \\
\text { Variable) } \\
\end{array}$ & CIT & $\begin{array}{l}\text { Annual company income tax } \\
\text { value }\end{array}$ & $\begin{array}{l}\text { CBN Statistical } \\
\text { bulletin, FIRS, }\end{array}$ & - \\
\hline 3. & $\begin{array}{l}\text { Value Added Tax } \\
\text { (Independent } \\
\text { Variable) }\end{array}$ & VAT & $\begin{array}{l}\text { Annual VAT value paid by } \\
\text { operating entities }\end{array}$ & $\begin{array}{l}\text { CBN Statistical } \\
\text { bulletin, FIRS, }\end{array}$ & - \\
\hline 4. & $\begin{array}{l}\text { Tertiary Education } \\
\text { Tax } \\
\text { (Independent } \\
\text { Variable) }\end{array}$ & TET & $\begin{array}{l}\text { Annual Education tax paid } \\
\text { by operating entities }\end{array}$ & $\begin{array}{l}\text { CBN Statistical } \\
\text { bulletin, FIRS }\end{array}$ & - \\
\hline 5. & $\begin{array}{l}\text { Custom and } \\
\text { Excise Duties } \\
\text { (independent } \\
\text { Variable) }\end{array}$ & CEDUT & $\begin{array}{l}\text { Cumulative annual value of } \\
\text { custom and excise duties } \\
\text { paid by companies in } \\
\text { Nigeria }\end{array}$ & $\begin{array}{l}\text { CBN Statistical } \\
\text { bulletin, FIRS }\end{array}$ & - \\
\hline 6. & $\begin{array}{l}\text { Official exchange } \\
\text { rate } \\
\text { (independent } \\
\text { Variable) } \\
\end{array}$ & EXRT & $\begin{array}{l}\text { The rate at which Naira } \\
\text { exchanges for U.S. Dollar }\end{array}$ & $\begin{array}{l}\text { World development } \\
\text { indicators of World } \\
\text { Bank }\end{array}$ & - \\
\hline 7. & $\begin{array}{l}\text { Inflation rate } \\
\text { (independent } \\
\text { Variable) } \\
\end{array}$ & INFL & $\begin{array}{l}\text { Consumer price index in } \\
\text { Nigeria }\end{array}$ & $\begin{array}{l}\text { World development } \\
\text { indicators of World } \\
\text { Bank, }\end{array}$ & - \\
\hline 8. & $\begin{array}{l}\text { Real GDP growth } \\
\text { rate } \\
\text { (independent } \\
\text { Variable) }\end{array}$ & RGDPGR & $\begin{array}{l}\text { Annual growth rate of real } \\
\text { Gross Domestic Products in } \\
\text { Nigeria }\end{array}$ & $\begin{array}{l}\text { World development } \\
\text { indicators of World } \\
\text { Bank }\end{array}$ & + \\
\hline 9. & $\begin{array}{l}\text { Trade Openness } \\
\text { (independent } \\
\text { Variable) }\end{array}$ & TOPN & $\begin{array}{l}\text { The ratio of Net exports } \\
\text { (Exports less Imports)to real } \\
\text { Gross Domestic Products in } \\
\text { Nigeria }\end{array}$ & $\begin{array}{l}\text { World development } \\
\text { indicators of World } \\
\text { Bank }\end{array}$ & + \\
\hline
\end{tabular}

\section{Results and Discussions}

This segment entails the model estimation results and presents the discussion of the empirical findings for the period 1983-2017

Testing for Stationarity (Unit Root tests) for the period

Unit Root tests are carried out to ascertain whether a time series variable is stationary or not. Table $2 \mathrm{~A}$ and Table $2 \mathrm{~B}$ report the results of the stationarity tests using both the Augmented Dickey-Fuller and Phillip-Perron tests of the time series employed in panel A and B below. The tables show the results of the piloted stationary tests at first difference. Custom and Excise Duty was also tested to validate the findings of Granger and Newbold (1977) which posits that a number of time series variables at certain levels often drift in non-stationary manner. Consequently, utilizing such non-stationary series might result in spurious regression outcomes.

The results show that all the variables under consideration have first-order integration (all stationary at first difference) in both test results. From the stationarity test results, all the series were stationary at 1 per cent significance level (except Value Added Tax, which became stationary at 5 per cent significance level in both the Augmented Dickey-Fuller and Phillip-Perron test results). This supports the choice of the Error Correction Modeling (ECM) approach of (Granger \& Newbold, 1977). 
Table 2A: Stationarity Test: Augmented Dickey-Fuller Approach

\begin{tabular}{|c|c|c|c|c|c|}
\hline \multirow{2}{*}{ Variables } & \multirow{2}{*}{ Test statistic } & \multicolumn{3}{|c|}{ Critical values } & \multirow{2}{*}{ Remarks } \\
\hline & & 1per cent & 5per cent & 10per cent & \\
\hline \multicolumn{6}{|c|}{ Panel A. Augmented Dickey-Fuller Tests Results } \\
\hline CEDUT & -1.45 & -3.62 & -2.94 & -2.61 & Not Stationary at Leve \\
\hline $\mathrm{D}(\mathrm{CEDUT})$ & -7.79 & -3.63 & -2.95 & -2.61 & Stationary*** \\
\hline $\mathrm{D}(\mathrm{CIT})$ & -8.76 & -3.63 & -2.95 & -2.61 & Stationary*** \\
\hline $\mathrm{D}(\mathrm{TET})$ & -5.67 & -3.63 & -2.95 & -2.61 & Stationary*** \\
\hline $\mathrm{D}(\mathrm{EXRT})$ & -4.53 & -3.63 & -2.95 & -2.61 & Stationary*** \\
\hline $\mathrm{D}(\mathrm{FDI})$ & -7.91 & -3.63 & -2.95 & -2.61 & Stationary*** \\
\hline $\mathrm{D}$ (INFL) & -4.67 & -3.63 & -2.95 & -2.61 & Stationary*** \\
\hline D(RGDPGR) & -9.33 & -3.63 & -2.95 & -2.61 & Stationary*** \\
\hline $\mathrm{D}(\mathrm{TOPN})$ & -6.81 & -3.63 & -2.95 & -2.61 & Stationary*** \\
\hline $\mathrm{D}(\mathrm{VAT})$ & -3.37 & -3.63 & -2.95 & -2.61 & Stationary** \\
\hline
\end{tabular}

NB: *Significant at 10per cent, **Significant at 5per cent, and ***Significant at 1per cent.

Source: Author's Computation using E-views

Table 2B: Stationarity Test: Phillips-Perron Approach

\begin{tabular}{|c|c|c|c|c|c|}
\hline \multirow{2}{*}{ Variables } & \multirow{2}{*}{$\begin{array}{c}\text { Test } \\
\text { statistic }\end{array}$} & \multicolumn{3}{|c|}{ Critical values } & \multirow{2}{*}{ Remarks } \\
\cline { 3 - 5 } & \multicolumn{7}{|c|}{ Panel B. Phillips-Perron Tests Results } \\
\hline \multicolumn{7}{|c|}{ CEDUT } & -1.16 & -3.62 & -2.94 & -2.61 & Not Stationary at Level \\
\hline D(CEDUT) & -7.58 & -3.63 & -2.95 & -2.61 & Stationary*** \\
\hline D(CIT) & -6.14 & -3.63 & -2.95 & -2.61 & Stationary*** \\
\hline D(TET) & -6.98 & -3.63 & -2.95 & -2.61 & Stationary*** \\
\hline D(EXRT) & -5.93 & -3.63 & -2.95 & -2.61 & Stationary*** \\
\hline D(FDI) & -7.91 & -3.63 & -2.95 & -2.61 & Stationary*** \\
\hline D(INFL) & -9.25 & -3.63 & -2.95 & -2.61 & Stationary*** \\
\hline D(RGDPGR) & -8.97 & -3.63 & -2.95 & -2.61 & Stationary*** \\
\hline D(TOPN) & -7.54 & -3.63 & -2.95 & -2.61 & Stationary*** \\
\hline D(VAT) & -3.24 & -3.63 & -2.95 & -2.61 & Stationary** \\
\hline
\end{tabular}

NB: *Significant at 10 per cent, $* *$ Significant at 5 per cent, and *** Significant at 1 per cent.

Source: Author's Computation using E-views

Co-Integration Test

Co-integration tests are generally carried out to determine the presence of long-run relationship among the variables in a Regression equation. This study adopts the procedure advanced by Johansen (1988) as well as Johansen and Juselius (1990). Using the approach presented by Johansen and Juselius (1990), the Max-Eigen and Trace statistic was utilized to evaluate the number of possible co-integrating vectors. The test statistics however dispels the null hypothesis of no co-integration. In a nutshell, the co-integration results reveal evidence of cointegrating relationships as shown by the significance of the Fisher statistics from Trace test and that from MaxEigen test results presented in Table $2 C$. This further validates the choice of the estimation technique, since the underlying theory is predicated on stationarity and co-integration assumptions (Enders, 1995). Table 2C shows the report of the results obtained from the Johansen co-integration rank tests. 
Table 2C: Johansen-Fisher Cointegration Test Results

Trend assumption: Linear deterministic trend (restricted)

Series: CEDUT CIT TET EXRT FDI INFL RGDPGR TOPN VAT

\begin{tabular}{|c|c|c|c|c|}
\hline \multicolumn{2}{|c|}{ Hypotheses } & \multirow{2}{*}{$\begin{array}{c}\text { Test statistic } \\
\mathbf{p}=18\end{array}$} & \multicolumn{2}{|c|}{ Critical values } \\
\hline Null Hypothesis & Alternative & & 5 per cent & 1 per cent \\
\hline \multicolumn{5}{|c|}{ Panel E. $\lambda_{\text {trace-statistic }}$} \\
\hline $\mathrm{H}_{0}: \mathrm{r}=0$ & $\mathrm{H}_{1}: \mathrm{r}=1$ & $394.0591 * *$ & 192.89 & 204.95 \\
\hline $\mathrm{H}_{0}: \mathrm{r} \leq 1$ & $\mathrm{H}_{1}: \mathrm{r}=2$ & $264.7684 * *$ & 156.00 & 168.36 \\
\hline $\mathrm{H}_{0}: \mathrm{r} \leq 2$ & $\mathrm{H}_{1}: \mathrm{r}=3$ & $180.6487 * *$ & 124.24 & 133.57 \\
\hline $\mathrm{H}_{0}: \mathrm{r} \leq 3$ & $\mathrm{H}_{1}: \mathrm{r}=4$ & $118.0824 * *$ & 94.15 & 103.18 \\
\hline $\mathrm{H}_{0}: \mathrm{r} \leq 4$ & $\mathrm{H}_{1}: \mathrm{r}=5$ & $74.03887 *$ & 68.52 & 76.07 \\
\hline $\mathrm{H}_{0}: \mathrm{r} \leq 5$ & $\mathrm{H}_{1}: \mathrm{r}=6$ & 32.88186 & 47.21 & 54.46 \\
\hline $\mathrm{H}_{0}: \mathrm{r} \leq 6$ & $\mathrm{H}_{1}: \mathrm{r}=7$ & 14.89417 & 29.68 & 35.65 \\
\hline $\mathrm{H}_{0}: \mathrm{r} \leq 7$ & $\mathrm{H}_{1}: \mathrm{r}=8$ & 6.009276 & 15.41 & 20.04 \\
\hline $\mathrm{H}_{0}: \mathrm{r} \leq 8$ & $\mathrm{H}_{1}: \mathrm{r}=9$ & 0.441500 & 3.76 & 6.65 \\
\hline \multicolumn{5}{|c|}{ Panel F. $\lambda_{\max }$-statistic } \\
\hline $\mathrm{H}_{0}: \mathrm{r}=0$ & $\mathrm{H}_{1}: \mathrm{r}=1$ & $129.2908 * *$ & 57.12 & 62.80 \\
\hline $\mathrm{H}_{0}: \mathrm{r} \leq 1$ & $\mathrm{H}_{1}: \mathrm{r}=2$ & $84.11964 * *$ & 51.42 & 57.69 \\
\hline $\mathrm{H}_{0}: \mathrm{r} \leq 2$ & $\mathrm{H}_{1}: \mathrm{r}=3$ & $62.56630 * *$ & 45.28 & 51.57 \\
\hline $\mathrm{H}_{0}: \mathrm{r} \leq 3$ & $\mathrm{H}_{1}: \mathrm{r}=4$ & $44.04358^{*}$ & 39.37 & 45.10 \\
\hline $\mathrm{H}_{0}: \mathrm{r} \leq 4$ & $\mathrm{H}_{1}: \mathrm{r}=5$ & $41.15701 * *$ & 33.46 & 38.77 \\
\hline $\mathrm{H}_{0}: \mathrm{r} \leq 5$ & $\mathrm{H}_{1}: \mathrm{r}=6$ & 17.98769 & 27.07 & 32.24 \\
\hline $\mathrm{H}_{0}: \mathrm{r} \leq 6$ & $\mathrm{H}_{1}: \mathrm{r}=7$ & 8.884896 & 20.97 & 25.52 \\
\hline $\mathrm{H}_{0}: \mathrm{r} \leq 7$ & $\mathrm{H}_{1}: \mathrm{r}=8$ & 5.567776 & 14.07 & 18.63 \\
\hline $\mathrm{H}_{0}: \mathrm{r} \leq 8$ & $\mathrm{H}_{1}: \mathrm{r}=9$ & 0.441500 & 3.76 & 6.65 \\
\hline
\end{tabular}

Source: Author's Computation

Parsimonious Error Correction Estimates for the period

The general objective of evaluating the impact of Corporate Taxes (Custom and Excise Duty, Company Income Tax, Tertiary Education Tax and Value Added Tax) on Foreign Direct Investments in Nigeria was accomplished with the aid of the Error correction modeling approach (ECM). Having ascertained that the variables are stationary at first difference and co-integrated, a parsimonious error correction equation is specified in order to capture the short-run dynamics that might have resulted in the course of estimating the long-run co-integrating vectors.

Thus, the parsimonious error correction model accomplishes this by presenting an error correction variable (ECM (-1)) which enable us to determine the speed of adjustment of Foreign Direct Investment in Nigeria to its long-run convergence (stability). This implies that, the error correction model is a combination of both the long run and short run representations. The model further captured a period Dummy (T93) which controls for the effect of missing cases from 1983 to 1993 . The Dummy was constructed such that, $\mathrm{t}=0$ for missing cases (1983 to 1993) and $\mathrm{t}=1$ for 1994 to 2017 .

The result of the error correction model reveals that, previous year innovations in FDI have statistically significant positive relationship with its current level (at 1 per cent significance level). The implication of the above finding is that, there is tendency for both existing and prospective foreign investors to examine the previous size of foreign investments in order to make informed decision regarding fresh injection/inflows of FDI into the country. However, a negative relationship was ascertained between Company Income Tax Rates and FDI at 1 per cent test level. The implication of this finding is that, higher company income tax affects the revenue-generating capacity of the foreign investors which has the propensity to cripple their desire and ability to expand their investment horizon in the host economy, and thus, deteriorate the level of FDI in the country. This result is in consonance with the tax competition theory propounded by Oates (1972) and substantiates previous findings of Saidu (2015) and Amuka and Ezedueka (2017), where they averred that a high company income tax jeopardizes economic expansion and deters foreign direct investment flows. Explicitly, the result implies that, a rise in Company Income Tax by one unit ceteris paribus, will lead to a corresponding decline in the level of FDI in the country by about 0.60 unit.

Furthermore, the coefficient representing Value Added Tax reveals a negative and statistically significant relationship (at 1 per cent test level) between Value Added Tax and FDI. The result corroborates previous findings of Hess (2000), Mintz (2004), Jr-tsung and Shih-tsung (2007), Olaleye et al (2016) who found that an increase in VAT increases operational cost which negates profit maximization and business expansion. Precisely, the result implies that, 1 unit fall in Value Added Tax rates ceteris paribus; will occasion a proportionate improvement in 
FDI by 1.66 units. Conversely, this indicates a statistically significant positive association (at 1per cent level) between Tertiary Education Tax and FDI. This result further negates previous findings of Akinwunmi et al. (2017) which showed that Tertiary Education Tax negatively and significantly impacts on FDI, suggesting that an increase in Tertiary Education Tax will lead to a decrease in FDI.

In addition, the coefficient of Custom and Excise Duty reveals a statistically significant negative relationship (at 5per cent level) between Custom and Excise Duty and FDI in Nigeria. Importantly, it is imperative to note here that, policy shocks resulting from an incessant and persistent increase in Custom and Excise Duties can lead to a considerable contraction in FDI owing to the circumlocutory distortions which translate into hike in the cost of factor inputs by way of additional tax burden borne by importers of tangible assets as well as unwarranted tax burden imposed on local manufacturers (Akinwunmi, et al. 2017). In addition, the result revealed that a 0.71 unit rise in the country's FDI is due to 1 unit fall in the country's Custom and Excise Duties.

Furthermore, Exchange rate was found to have a statistically significant adverse impact (at 1 per cent level) on FDI in Nigeria. This is indicative of the fact that, exchange rate depreciation worsens real income and export earnings as locally made goods are exchanged at cheap rates. It therefore, implies that, deteriorating exchange rate affects foreign investments in two ways. First, it increases the cost of importing factor inputs like machinery, office equipment and other fixed assets. This discourages foreign investors particularly those in the construction, manufacturing and transport sectors who depends on the importation of factor inputs. In addition, a dwindling exchange rate causes a depressive effect on export earnings as locally manufactured goods are exported at cheap rates. This further serves as a disincentive to local manufacturers and as such, foreign investors in the manufacturing sectors are greatly affected. More to the above point, the result indicates that, about 2.97 units decline in the level of FDI flows can be attributed to 1 unit deterioration in the value of domestic currency (Nigerian Naira). Interestingly, this result is in consonance with earlier findings of Okwuchukwu (2015), Mbanasor and Obioma (2017), Ndanu and Kennedy (2018).

From the result also, the coefficient of inflation rate, though, contrary to a priori expectation, reveals a statistically insignificant positive association between FDI and a persistent rise in general price level. In reality, when inflation rate rises; monetary authorities increase interest rates to reduce the money supply and when interest rates are high, people find it expensive to borrow, and therefore there is less money floating around. When this happens, investors whether foreign or domestic, get very nervy because of the potential impact of price adjustments on their investment. When investors decline to invest, this leads to a decline in productivity and further cripples the level of FDI flows into the host economy. This finding however validates previous findings of (Khamis et al. 2015; Ndanu \& Kennedy, 2018).

The result revealed that, real GDP growth rate impacts positively on FDI flow (at 95 per cent confidence level). This is predicated on the fact that as the economy grows consistently, this will boost foreign investors' confidence and hence, the urge to invest in the host economy so as to further contribute to the host economy while reaping the dividends of such expansion. Such desire to commit resources into the host economy will trigger a rise in the flows of FDI in the country. This is in consonance with earlier findings of Tampakoudis, et al (2017) and Marija et al. (2017) who advanced that, the destination for FDI flows is scanned for the potential of the host economy both in terms of future market size as well as of improved market.

Also, the coefficient of Trade Openness shows that, Trade Openness has a positive impact on FDI flows. The implication of the above finding is that, as the economy becomes more liberal in its foreign trade policies, it will trigger the desire of foreign investors to invest in the host economy and as a result, a rise in the level of FDI flows will set in and this is statistically significant at 1.0 percent level as revealed by the resulting t-ratio. This finding further corroborates to earlier findings of Mputu (2016); Samiyah and Sakib (2018). The higher the degree of openness to trade beyond national boundaries, the higher the flow of investments and increased trade openness leads to a rise in money circulation in the economy, as it gives room for influx of foreign currency flows and investments.

The error correction term (ECM) is both negative and statistically significant, showing that an established long-run relationship can be attained. The speed of adjustment shows that about 75 percent of the short-run dynamics in FDI from is corrected every year. The coefficient of determination $\left(\mathrm{R}^{2}\right)$ showed that, about 77 per cent of the systematic changes in FDI are attributed to the combined effect of all the explanatory variables captured in the study, while the remaining 23 per cent is due to the stochastic disturbance term. The F-statistics indicate that the explanatory variables are simultaneously significant when addressing issues relating to FDI in Nigeria. From the Error Correction result, the Durbin Watson statistic was 2.04 (See Table 2D). This indicates that, autocorrelation is absent in the estimated ECM model. 
Table 2D: Parsimonious Error Correction Estimates for the period 1983-2017

Dependent Variable: D(FDI)

Method: Least Squares

\begin{tabular}{|c|c|c|c|c|}
\hline Variable & Coefficient & Std. Error & t-Statistic & Prob. \\
\hline C & 4.33 & 3.05 & 1.42 & 0.15 \\
\hline D(FDI(-1)) & 0.27 & 0.11 & 2.48 & $0.00^{* * *}$ \\
\hline D(CIT) & -0.6 & 0.19 & -3.16 & $0.00^{* * *}$ \\
\hline D(VAT) & -1.66 & 0.35 & -4.67 & $0.00^{* * *}$ \\
\hline D(TET) & 1.15 & 0.33 & 3.52 & $0.00^{* * *}$ \\
\hline D(CEDUT) & -0.71 & 0.27 & -2.58 & $0.02^{* *}$ \\
\hline D(EXRT) & -2.97 & 1.02 & -2.92 & $0.00^{* * *}$ \\
\hline D(INFL) & 0.18 & 0.2 & 0.88 & 0.41 \\
\hline D(RGDPgr) & 2.74 & 1.28 & 2.14 & $0.04 * *$ \\
\hline D(TOPN) & 3.52 & 1.32 & 2.67 & $0.01 * * *$ \\
\hline ECM(-1) & -0.75 & 0.26 & -2.87 & $0.00^{* * *}$ \\
\hline T93 & -21.72 & 21.08 & -1.03 & 0.31 \\
\hline R-squared & 0.77 & Durbin-Watson stat & 2.04 \\
\hline Adjusted R-squared & 0.68 & \multicolumn{2}{|c|}{ Wald F-statistic } & 417.48 \\
\hline F-statistic & 7.47 & Akaike info criterion & 13.16 \\
\hline Prob(F-statistic) & 0 & \multicolumn{2}{|c|}{ Schwarz criterion } & 13.69 \\
\hline Prob(Wald F-statistic) & 0 & Hannan-Quinn criter. & 13.35 \\
\hline
\end{tabular}

NB: *Significant at 10 per cent, **Significant at 5 per cent, and ***Significant at 1 per cent.

Source: Author's Computation using E-views

\section{Parameter Stability Analysis}

In this segment, we evaluate the stability properties of the parameters in the model by employing the plots of the Cumulative Sum of Recursive Residual (CUSUM) in addition to the Cumulative Sum of Squares of Recursive Residual (CUSUMsq). It is worth noting that, while the CUSUM test is appropriate for identifying systematic dynamics in the regression parameters, the CUSUMsq is used in situations where the deviation from the stability of the regression coefficients is sudden and unexpected. Consequently, from the graphs presented in figure 1a and $1 \mathrm{~b}$, the CUSUM and CUSUM of Squares remained within the 5 percent critical lines throughout the whole period (except for CUSUM of Squares, 2003 with a slight drift) thus, signifying parameter stability during the course of analyses.

Figure 1A: CUSUM Test Result for the period 1983-2017

Figure 1B: CUSUM of Squares Test Result for the period 1983-2017
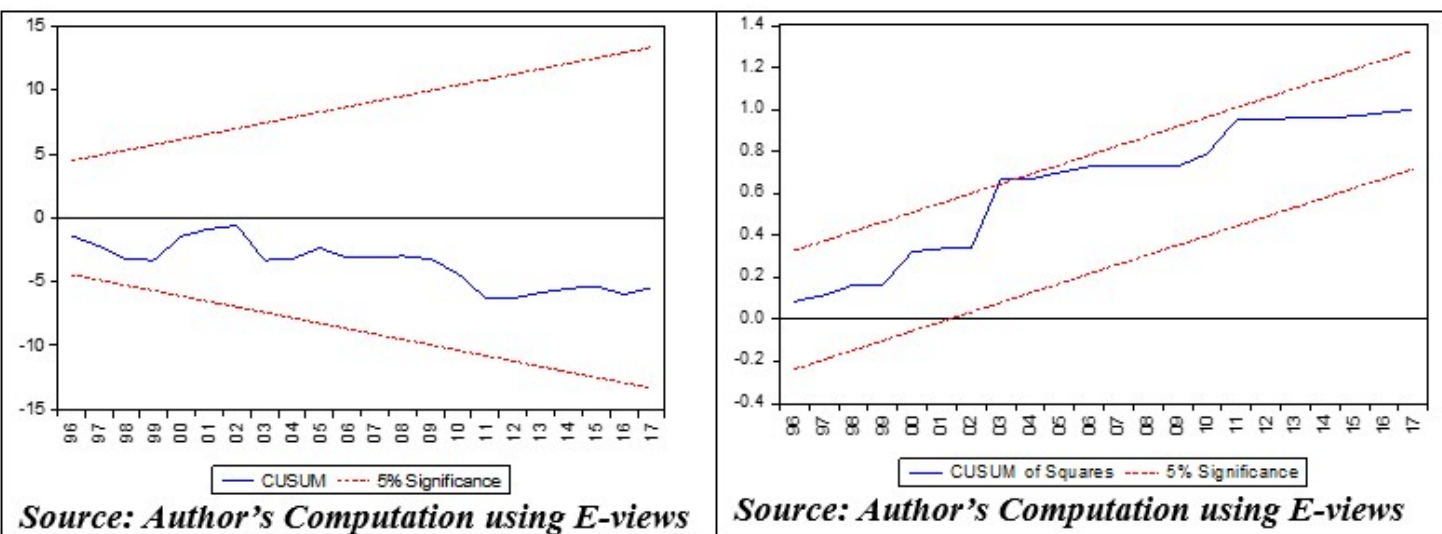

\section{Conclusion}

The conflicting view of several studies on the effect of taxes on FDI motivated the investigation into the study. While some argued that taxes affect the flow of FDI into an economy, others hold a contrary view. However, based on our findings, the estimates reveal that higher company income taxes, value-added tax and custom and excise duty affect the propensity to invest in the country. On the other hand, tertiary education tax influences the flow of 
FDI. Exchange rate depreciation has a negative relationship with FDI, hence distort the flow of FDI, GDP growth rate and trade openness advance the flow of FDI while a positive association exists between inflation rate and FDI.

The study recommends an overhaul of the Nigerian business environment and a review of its fiscal policies. A reduction in company income taxes will support local and foreign investors, and an upward revision of the tertiary education tax will help boost the managerial and technical skills necessary to support domestic and foreign businesses. More so, macroeconomic adjustments and policies are required to reduce the nation's overall dependence on imports. This will be positive for its balance of payment, decrease the inflationary pressure on the naira and enhance a liberal foreign policy that would drive investments to the country.

The study focused on company income tax, value-added tax, education tax and custom and excise duties without other corporate tax variables such as Petroleum profit tax and capital gains tax. This limits our ability to uncover the reaction of FDI to taxes in all sectors, including the oil and gas industry. Nigeria draws in huge investment interest in the oil and gas industry, therefore the aftereffect of this investigation may not be summed up to the oil and gas industry.

Consequently we recommend that petroleum profit tax and capital gains tax ought to be variables for further investigation as this might provide additional insight to the impact of corporate taxes on the flow of FDI in the country.

\section{References}

Aderibigbe, V. (2017, September 11). Is Nigeria still the giant of Africa? The Guardian. Retrieved from https://guardian.ng/opinion/is-nigeria-still-the-giant-of-africa/

Akinwunmi, A., Olotu, A., \&Adegbie, F. (2017). Multiplicity of taxes and foreign direct investment: A relational analysis of Nigerian tax environment. Social Sciences, 6(4), 94-101. https://doi:10.11648/j.ss.20170604.11

Amuka, J., \& Ezeudeka, F. (2017). Tax incentives and the flow of foreign direct investment to non-oil sector: Empirical. Asian Journal of Social Sciences and Management Studies, 4(1), 57-64

Andre, F. (2015). Tax Effects in Portugal. Lisbon School of Economics and Management.

Arnold, J., \&Cyrille, S. (2008). Do corporate income taxes reduce productivity and investment at the firm level? Cross-Country evidence from the Amadeus Dataset. Retrieved from https://www.ecn.ulaval.ca/ sgor/cit/schwellnus_oecd_2008/schwellnus_oecd_2008.pdf

Babatunde, B., \&Adepeju, S. (2012). The impact of tax incentives on foreign direct investment in the oil and gas sector in Nigeria. Journal of Business and Management, 6(1), 1-15.

Bajrami, H., \& Nazmi, Z. (2019). Theories of foreign direct investment (FDI) and the significance of human capital. International Journal of Business and Management, 52(1), 11-24. https://doi.org/10.20472/BM.2019.7.1.002

Camara, O. B. (2014).Effect of corporate tax on sector specific foreign direct investment in Ghana.Munich Personal RePEc Archive. Retrieved from https://mpra.ub.unimuenchen.de/58454/1/MPRA_paper_58454.pdf

Cassou, S. P. (2006). The link between tax rates and foreign direct investment. Journal of Applied Economics, $29(10), 1295-1301$.

Cung, N. H., \&Hua, L. (2013). Tax burden and foreign direct investment: Theory and practice in Vietnam. Advances in Management \& Applied Economics, 3(3), 85-103.

De Mooij, R., \& Ederveen, S. (2006). Taxation and foreign direct investment: A synthesis of empirical research. International Tax and Public Finance, 10, 673-693.

Deloitte.(2018).Corporate tax rates: International tax. Retrieved from https:/deloitte.com/content/dam/Deloitte/global/Documents/Tax/dttl-tax-corporate-tax-rates.pdf

Dickey, D. A. \&Fuller, W.A. (1981), Likelihood ratio statistics for autoregressive time series with a unit root. Econometrica, 49(4), 1057-1072. https://doi.org/10.1016/j.eneco.2010.08.003

Djankov, S. (2017).Corporate tax Cuts: Examining the record in other countries (Issue brief No. 17-14.

Dragoș, P. N. (2013). Taxation and its effect on foreign direct investments - The case of Romania.Financial Sciences, 3(16).

Enders, W. (1995). Applied Econometric Time series. New York: John Wiley

George, T., \& Bariyima, D. (2015).Tax incentives and foreign direct investment in Nigeria. IOSR Journal of Economics and Finance, 6(5), 10-20, https://doi:10.9790/5933-06511020

Golpira, E., Abdolreza, E., \&Rui, L. (2016).Corporate income tax as a determinant of foreign direct investment in Central and Eastern Europe.. European Journal of Business and Social Sciences, 4(11), 111-123.

Granger, C. W. J., \&Newbold, P. (1974).Spurious regressions in econometrics. Journal of Econometrics, 2, 111 120.

Haberly, D., \&Wojcik, D. (2014).Regional blocks and imperial legacies: Mapping the global offshore FDI network (Working paper No. 13-07).

Hansson, A., \&Olofsdotter, K. (2010). Tax differences and foreign direct investment in the EU27 (Working paper). 
SWOPEC

Hess, R. (2000). Constraints on foreign direct investment. In C. Jenkins., L. Thomas.,\& L. Leape (Eds.), Gaining from trade in Southern Africa: Complementary policies to underpin the SADC free trade area. London: Macmillan.

Hunady, J., \& Orviska, M. (2014). Determinants of foreign direct investment in E.U. countries: Do corporate taxes really matter? Procedia Economics and Finance,12(2014), 243-250, https://doi.org/10.1016/S22125671(14)00341-4

Hungerford, T. L. (2012). Taxes and the economy: An economic analysis of the top tax rates since 1945 (Updated). Washington, DC: Congressional Research Service.

Johansen, S. (1988), Statistical analysis of co-integration vectors. Journal of Economic Dynamics and Control, 12(2-3), 231-254.

Johansen, S. and Juselius, K. (1990).Maximum Likelihood Estimation and Inference on Co-integration-With Applications to the Demand for Money.Oxford Bulletin of Economics and Statistics 52: 169-210.

Jr-tsung, H., \& Shih-tsung, L. (2007). China's VAT on foreign enterprises and its impact on attracting investments by local governments. Prospect Quarterly. Retrieved from nccu.edu.tw/ jthuang/QM-01.pdf

Julio, P., Alves, P., \& Tavares, J. (2013). Foreign direct investment and institutional reform: Evidence and an application to Portugal. Portuguese Economic Journal,12, 215-250., http:// 10.1007/s10258-013-0093-z

Kersn-Skabic, I. (2015). The Importance of corporate taxation for FDI attractiveness of Southeast European countries.Panoeconomicus, 62(1), 105-122

Khamis, H. A., Mohd H. \& Muhammad A. (2015). The impact of inflation and GDP per capita on foreign direct investment: The case of United Arab Emirates. Investment Management and Financial Innovations, 12(3-1), $132-141$

Kinda, T. (2014).The Quest for non-recourse based foreign direct investment: Do tax Matter?(Working paper No. $14 / 15)$.

Kubicova, J. (2013). The Role of corporate income tax in foreign direct investment inflows into the 'old' and 'new' E.U. member states.Research Project VEGA,1(13), 222-233.

Marija P. R., Vesna J. M., and Ivana K. (2017).Market size as a determinant of foreign direct investment inflows in the Western Balkans countries. Economics and Organization.14(2), 93-104.

Mbanasor, C., \& Obioma, J.( 2017). Exchange rate fluctuations and foreign private investments in Nigeria.IIARD International Journal of Economics and Business Management.3,(8) 1-23

Mintz, J. M. (2004). The changing structure of tax policies for foreign direct investment in developing countries.International Studies Program Public Finance Conference.Retrieved from issuelab.org/resources/5252/5252.pdf.

Morisset, J. (2000). Foreign Direct Investment in Africa : Policies Also Matter. Policy Research Working Paper;No. 2481. World Bank, Washington, DC.World Bank. https://openknowledge.worldbank.org/handle/10986/19748 License: CC BY 3.0 IGO.

Mputu, C. (2016).Terms of trade, trade openness and economic growth in Sub-Saharan Africa Culminating $\begin{array}{lllll}\text { Projects in } & \text { Economics. } & 3 . & \text { Retrieved }\end{array}$ https://repository.stcloudstate.edu/cgi/viewcontent.cgi?referer=https://www.google.com/\&httpsredir=1\&arti cle $=1001 \&$ context $=$ econ_etds

Musyoka, K. (2012). The relationship between tax incentives and foreign direct investment in Kenya, University of Nairobi, Kenya.

National Tax Policy. (2012).

Ndanu M. \& Kennedy O. (2018).Real interest rate, inflation,exchange rate, competitiveness and foreign direct investment in Kenya.American journal of economics 3(1), 1-18.

Nikula, N., \&Kotilainen, M. (2012).Determinants for foreign direct investment in the Baltic Sea region (Rep. No. 1).ETLA.

Oates, W. (1972).Fiscal federalism. New York: Harcourt Brace Jovanovich

Obida, G., \&, Nurudeen, A. (2010). Determinants of foreign direct investment in Nigeria: An empirical analysis, Global Journal of Human Social Science, 10(1), 26-34.

Odhiambo, I. (2013). The relationship between corporate tax and investment in Kenya, University of Nairobi. Kenya

Oguh, C. (2016, December 7). Why Nigeria no longer attracts foreign direct investment. Financial Nigeria. Retrieved from http://www.financialnigeria.com/why-nigeria-no-longer-attracts-foreign-direct-investmentblog-194.html

Okafor, A. (2019). Refocusing on the success enabling factors in mergers and acquisitions. European Scientific Journal 15(16), 172-190, https://doi.org/10.19044/esj.2019.v15n16p172

Okolo, E., Okpalaojiego, E., \&Okolo, C. (2016). Effect of multiple taxation on investments in small and medium enterprises in Enugu State, Nigeria.International Scholarly and Scientific Research and Innovation, 10(1), 
378-386, http:// doi.org/10.5281/zenodo.1123971

Okwuchukwu, O. (2015). Exchange rate volatility, stock market performance and foreign direct investment in Nigeria.International Journal of Academic research in Accounting, Finance and Management sciences. 5(2), 172-184.

Olaleye, M. (2016).Effect of tax incentives on foreign direct investment in listed Nigerian manufacturing companies.(Doctoral dissertation).Jomo Kenyatta University of Agriculture and Technology, Kenya.

Olaniyi, T. A., Ajayi, R. O., \& Oyedokun, G. E. (2018). Tax policy incentives and foreign direct investment in Nigeria. Fountain University Osogbo Journal of Management, 3(3), 59-71.

Phillips, P. C. B., and Perron P. (1988), Testing for a unit root in time series regression. Biometrika, 75(2), 335346.

Saidu, A. (2015). Corporate taxation and foreign direct investment in Nigeria.European Journal of Accounting, Auditing and Finance Research, 3(8), 17-24

Samiyah H, \& Sakib B.(2018). Foreign direct investment, trade openness and economic growth: The case of Bangladesh. World Review of Business Research.8 (3), 104-125.

Santiago, A. O., \& Yoo, J. (2012). Tax Composition and Growth: A Broad Cross-Country Perspective. International Monetary Fund, 12(257), 1-36.

Shafik, H., Martin. R. \& Alfons.W. (20011).The effects of taxation on the location decision of multinational firms: $M \& A$ vs greenfield investment.(Working paper).

Sheedy, E., Zhang, L., \& Tam, C. H. (2017). Are profit based incentives compatible with a risk culture? Experimental Research Report, 1-11.

Taiwo, J., Achugamonu, B., Okoye, O., \&Agwu.M. (2017). Foreign direct investment: Catalyst for sustainable economic development in Nigeria. Saudi Journal of Business and Management Studies. 2(2), 70-81, http:// doi: 10.21276/sjbms.2017.2.2.2

Tampakoudis, I.,Subeniotis., D., Kroustalis, I., \&Skouloudakis. M. (2017).Determinants of foreign direct investment in middle-income countries: New middle-income trap evidence. Mediterranean Journal of Social Sciences $8(1), 58-70$.

Tayo -Tiwo, A. (2020). Exploring how Nigeria bank regulators enforce compliance with the code of corporate governance. European Scientific Journal, 16(4), 14-28. http://dx.doi.org/10.19044/esj.2020.v16n4p14

Tessema, S.T. (2008). Competition to attract foreign direct investment through tax incentives as a threat for the realisation of socio-economic rights in Africa, University of Mauritius.

Ugwu, J. I. (2018). Tax incentives and foreign direct investment (FDI): Implication for export promotion in Nigeria, Ghana and South Africa, Post IFRS adoption. International Journal in Management and Social Science, 6(9), 31-52.

UNCTAD.(2017). World investment report: Investment and the digital economy. New York and Geneva: United Nations. United Nations Publication.

Wakaguyu, W., Mwangi, W., Kennedy, O., \& George, M. (2017). The relationship between tax burden and foreign direct investment inflows: A review of empirical literature. European Journal of Accounting, Auditing and Finance Research, 5(5), 66-77.

World Bank. (2018). Doing business 2018: Reforming to create jobs. Retrieved from http://www.doingbusiness.org/ /media/WBG/DoingBusiness/Documents/AnnualReports/English/DB2018-Full-Report.pdf

World Health Orgnaisation (2020). Coronavirus- Covid 19 Situation Report149. Retrieved from:https://www.who.int/emergencies/diseases/novel-coronavirus-2019/situation-reports 